\title{
$X: 50486820-50492643$
}

National Cancer Institute

\section{Source}

National Cancer Institute. X: 50486820-50492643. NCI Thesaurus. Code C41789.

Physical location of BMP15_Gene 